This item was submitted to Loughborough's Research Repository by the author.

Items in Figshare are protected by copyright, with all rights reserved, unless otherwise indicated.

\title{
Teachers and didacticians: key stakeholders in the processes of developing mathematics teaching
}

\section{PLEASE CITE THE PUBLISHED VERSION}

http://dx.doi.org/10.1007/s11858-014-0574-2

\section{PUBLISHER}

Springer / @ FIZ Karlsruhe

VERSION

SMUR (Submitted Manuscript Under Review)

\section{PUBLISHER STATEMENT}

This work is made available according to the conditions of the Creative Commons Attribution-NonCommercialNoDerivatives 4.0 International (CC BY-NC-ND 4.0) licence. Full details of this licence are available at: https://creativecommons.org/licenses/by-nc-nd/4.0/

\section{LICENCE}

CC BY-NC-ND 4.0

\section{REPOSITORY RECORD}

Jaworski, Barbara, and Rongjin Huang. 2019. "Teachers and Didacticians: Key Stakeholders in the Processes of Developing Mathematics Teaching”. figshare. https://hdl.handle.net/2134/18202. 


\title{
Interactive practices in promoting professional development of didacticians and teachers of mathematics: An international perspective Editors Rongjin Huang and Barbara Jaworski
}

\section{Introductory article}

Teachers and didacticians: key stakeholders in the processes of developing mathematics teaching

\section{Barbara Jaworski and Rongjin Huang}

\begin{abstract}
This paper sets the scene for the special issue by tracing key elements of the fields of teacher and didactician learning related to the development of opportunities for learners of mathematics in classrooms. It starts from the perspective that joint activity of these two groups (teachers and didacticians), in creation of classroom mathematics, leads to learning for both. We trace development through key areas of research, looking at forms of knowledge of teachers and didacticians in mathematics; ways in which teachers or didacticians in mathematics develop their professional knowledge and skill; and the use of theoretical perspectives relating to studying these areas of development. Reflective practice emerges as a principal goal for effective development and is linked to teachers' and didacticians' engagement with inquiry and research. While neither reflection nor inquiry are developmental panaceas, we see collaborative critical inquiry between teachers and didacticians emerging as a significant force for teaching development. We include a summary of the papers of the special issue which offer a state of the art perspective on developmental practice.
\end{abstract}

\section{Introduction}

In this special issue we are concerned with the fundamental question of how teaching can develop to provide the best possible opportunities for learners of mathematics in classrooms. We focus on the development of teaching and consider the key stakeholders in this enterprise, the classroom teachers of mathematics, and how they contribute to developing teaching and learning practices in their classrooms. Moreover we focus on the roles and responsibilities of mathematics educators (sometimes called teacher-educators or didacticians ) who work with teachers to enable development to take place, and hence have their own forms of practice. In this introductory article, we set the scene by addressing the ways in which these two 
groups of practitioners ${ }^{1}$ work together to promote development. With support from relevant literature, we address questions concerning knowledge of the two groups, their particular practices, and relationships between them that contribute to the nature of development.

Various terms are used to refer to the mathematics educators who work with teachers in differing roles and contexts (Even 2008). We shall use these various terms as they are used in the literature to which we refer below. One of these terms, "didactician” perhaps needs further explanation. In this special issue, didacticians are mathematics (teacher-) educators who work with practising teachers to promote developments in teaching and learning mathematics: the term includes university faculty, teaching researchers, curriculum development coordinators, master teachers, mathematics coaches, and so on. 'Didactics' is about the transformation of disciplinary knowledge into forms through which learners can develop their own versions of that knowledge. We want students to learn mathematics, which is not easily accessible in the world around us. Students need to be offered tasks and activity through which to appreciate mathematics and develop mathematical concepts. The process of transforming mathematics into such opportunities for students is a didacticial process which is the practical task of the teacher of mathematics. A didactician of mathematics is aware of relevant theories, research findings, modes of practice and resources that support the teaching and learning of mathematics. Didacticians who are teacher-educators, work with practising or prospective teachers to enable a transformation of theoretical ideas and research findings into modes of teaching that are informed by theory and research. Here we see transformative work at two levels, one between didacticians and teachers and one between teachers and students. These are not separate, the first, if successful, highly informs the second, and the second feeds back to the first. Both didacticians and teachers have much to learn about the processes involved. Thus we see a didactical cycle focused on the knowledge and learning of teachers and didacticians which is central to the work reported in the papers here (see also the ZDM Issue focusing on the didactic triangle, Goodchild and Sriraman, 2012)

\footnotetext{
1 Practice and practitioners: we use these terms extensively in this article; often in relation to the ways they are used in the literature to which we refer. In broad terms, practice involves what people DO. In many cases it also includes how they think about what they do and the associated planning in which they engage. The practice always relates to the engagement of the practitioners (the people who practice) - for example, the practice of classroom teachers is likely to be different from that of university educators.
} 
As Even (2008) has pointed out, one of the challenges of educating mathematics teacher-educators - didacticians - to work with practicing teachers is a lack of research on the knowledge and practices of mathematics teacher-educators. She calls for investigating mathematics teacher-educators' practices cross-culturally. What we start to find, when we look cross-culturally, is a diversity of modes or models. As an example we point to a long tradition of school-based teaching-research in China (Huang and Li 2009; Yang 2009) which has demonstrated its power in promoting teachers' growth. This system has developed a "multiplicity of voices, including those of front-line teachers, experts, master teachers, and researchers, and the wisdom derived from the sustained interaction among them” (Tsui and Wong 2009, p.308). We see here the development of people who fit the description of didacticians emerging within the system. We are aware therefore that there is not always a clear distinction between practising teachers of mathematics and didacticians of mathematics. We shall leave it to the different papers in this special issue to make the distinction within their own context. In this introductory article, we use the term “didacticians” where it makes sense as a collective term. However, when drawing on the literature, we use also the terms that other authors use.

Thus, this special issue aims to address how didacticians and practising teachers, in a range of cultural settings and educational systems, can work together to create the best possible environments for students learning mathematics. Such activity enables development of the teachers' and didacticians' own professional capacities. In this article we address key literature in these areas and theory which has influenced research findings, with attention to the following questions:

1. What does research show us about how practising teachers in different communities develop their teaching knowledge and expertise through participating in programmes for mathematics teaching development?

2. What does research show us about how didacticians in different communities develop their professional knowledge and expertise through participating in programmes for mathematics teaching development?

3. What do we know as an international community about how interactions between these two groups leads to mutual learning and teaching development, and what do we still need to know? 


\section{Literature review}

To provide a foundation for addressing these questions, we explored relevant literature in three, interconnected areas:

(1) forms of knowledge teachers or didacticians in mathematics have, or need to have;

(2) ways in which teachers or didacticians in mathematics develop their professional knowledge and skill;

(3) theoretical perspectives relating to development of teaching by teachers or didacticians in mathematics.

Understanding of the nature of knowledge of teachers or didacticians in mathematics provides a base for discussing teachers and didacticians' learning and professional development. Theoretical perspectives equip researchers with frames to examine how professional learning takes place.

\subsection{Knowledge in and of teaching as related to teaching practice}

During the last two decades, growing attention has been given to studies of teachers' knowledge and its relations to teaching practice (e.g. Ponte and Chapman, 2006; Sullivan and Wood, 2008). Ponte and Chapman (2006), suggest that much attention has been paid to teachers' need to develop as reflective practitioners, they write:

... reflecting in-practice has to do with content and content-related pedagogical knowledge. It takes place when teachers deal with professional problems and therefore can be seen as part of their knowledge. (p. 461).

They draw on a wide literature on teacher and teaching development in which reflective practice has come to be seen as a central plank in the developmental process some of which we address further below. Here they link reflective practice to “content and content-related pedagogical knowledge”. Many sources draw on Shulman's (1986) framework of seven types of teacher knowledge [knowledge of content, general pedagogical knowledge, curriculum knowledge, pedagogical content knowledge (PCK), knowledge of students, knowledge of educational contexts, knowledge of educational ends, purposes and values]. Relationships between content knowledge (in our case mathematical knowledge) and pedagogical content knowledge have proved to be of particular interest to theorists and researchers who have further refined and developed models to describe and measure knowledge needed for teaching (e.g., Ball, Thames, and Phelps 2008; Hill, Ball, and Schilling 2008; Krauss et al. 
2008; Rowland, Huckstep and Thwaites. 2005; Silverman and Thompson 2008; Tatto et al. 2012). We do not have space here to explore such models in detail; rather we illustrate through a few widely referenced examples. At the University of Michigan, a research team built extensively on Shulman's categories, focusing on Mathematics Knowledge for Teaching (MKT), classifying MKT into four categories of Common Content Knowledge, Specialized Content Knowledge, Knowledge of Content and Students and Knowledge of Content and Teaching (Ball et al. 2008). In each of these categories the 'content' is mathematics: the differing categories emphasise that teachers' mathematical knowledge varies as it relates to differing aspects of their practice. Rowland, Huckstep, and Thwaites (2005) have also drawn on Shulman's categories in developing the Knowledge Quartet in which teachers' knowledge is seen to grow in and through four categories: foundation, transition, connection and contingency, each of which is related to aspects of teaching practice. Other studies have focused more overtly on knowledge-related aspects of teachers' practice. For example, the Teacher Education Development Study in Mathematics (TEDS-M; Tatto et al. 2012) measured teachers’ competences, including cognitive and affectivemotivational dimensions. The cognitive-motivation characteristics consist of content knowledge and pedagogical content knowledge, while affective-motivation characteristics include professional beliefs and self-regulation. Askew, Rhodes, Brown, Wiliam, and Johnson (1997) divide teachers into three groups according to their observed practice: transmissionist, discovery and connectionist teachers. These distinctions suggest differing elements in how teachers interpret their knowledge in practice. Jaworski (1994) suggests a triadic organization of teaching practice into management of learning, sensitivity to students and mathematical challenge, linking knowledge of mathematics with knowledge of students within a management of the learning environment. Throughout all these categorisations there is recognition that teachers need to have knowledge of mathematics, didactics and pedagogy; the various theories focus on the differing relationships between these three elements of knowledge for teaching and the practices with which they are associated. Common to all is, firstly, the recognition of the importance of mathematical knowledge; also called common or specialized content knowledge (Ball et al. 2008), referred to as foundation or connections (Rowland et al., 2005), and developed through mathematical challenge (Jaworski, 1994), and, secondly, the complexity of didatical or pedagogical content knowledge in relationships such as mathematics and students, 
mathematics and teaching (Ball et al., 2008; Jaworski, 1994), transition and contingency (Rowland et al., 2005).

In contrast, the knowledge required by didacticians has received relatively little attention, but is an emerging field of research (Beswick \& Chapman, 2012, 2013). Some scholars conceptualize didacticians' knowledge as an extension of the knowledge teachers need for teaching (Zaslavsky\& Leikin, 2004; Perks \&Prestage, 2008;). For example, Zaslavsky and Leikin (2004) extended the teaching triad idea (Jaworski 1994) to the work of teacher-educators. Just as teachers need to challenge students to engage with mathematical knowledge, teacher-educators need to challenge teachers to engage with knowledge of teaching mathematics: for example, becoming sensitive to their students cognitive and affective needs; offering challenging mathematical tasks etc. Perks and Prestage (2008) described a teacher-educatorknowledge-tetrahedron in which teacher-educator knowledge links to learner knowledge (i.e., the knowledge we develop from being teachers), practical wisdom (the activities chosen for teaching) and professional traditions (the existing mathematics teacher education course, ways of working with teachers, research on mathematics teaching and learning). These models suggest that teacher educators' knowledge should include how to support prospective and practicing teachers to develop teacher knowledge needed for teaching (Jaworski, 2008b). This suggests a need for didacticians to engage with knowledge for teachers.

However, Beswick and Chapman (2012) point to elements of mathematics teachers' knowledge that mathematics teacher educators either do not need to know, or need to know differently.

\footnotetext{
For example, mathematics teachers need to know about the school curriculum in considerable detail in order to teach it and to report students' attainment in relation to it. Mathematics teacher educators, however, need to know about school curricula but not in the detail needed by teachers who work with it daily and are accountable for outcomes it specifies. Rather, they need to know about curricula in a more general way, including how and to what extent research is reflected in them, and the overall expectations of the content teachers at different grade levels should be able to teach. Mathematics teacher educators' knowledge might, therefore, be seen as overlapping with mathematics teachers' knowledge but not entirely containing it (p. 3).
}

Rather than focusing on knowledge per se, research has explored the specific competences that teacher-educators need to develop (Smith, 2005; Even, 2008; Zaslavsky, 2008). Zaslavsky (2008) emphasized that among the enormous and multifaceted demands on mathematics teacher-educators, in term of knowledge and quality, the overarching demand is for teacher-educators (like teachers) to be reflective 
practitioners. They need to constantly reflect on-action and in-action (Schön, 1987) in all phases of their work. In this, she is in agreement with Smith (2005) (speaking of teacher-educators generally, not specially in mathematics) who writes that teachereducators should be able to

(1) be self-aware, reflect and articulate in-action reflections, to explain tacit knowledge of teaching;

(2) be comprehensive, rich and deep, based on theory and testing theories in practice;

(3) engage in curricula writing and research;

(4) be skillful in teaching all age groups of learners;

(5) have a comprehensive understanding of the educational system; and

(6) have achieved a high level of professional maturity. [pp. 182-183] Zaslavsky's own list of competencies is as follows:

(1) Developing adaptability;

(2) Fostering awareness to similarities and differences;

(3) Coping with conflicts, dilemmas and problem situations;

(4) Learning from the study of practices;

(5) Selecting and using (appropriate) tools and resources for teaching;

(6) Identifying and overcoming barriers to students’ learning; and

(7) Sharing and revealing self, peer, and students’ dispositions. (p. 95)

Similarly, in a study of Chinese practice-based mathematics teaching researchers' knowledge and competency, Huang et al. (2012) concluded that these researchers need to have expertise in conducting effective teaching, doing teaching research, effective organizing of school-based teaching activities, and evaluating teachers' teaching and students' learning. Although Zaslavsky and Huang and colleagues talk of mathematics education, their categories, like those of Smith, do not refer to mathematics specifically; perhaps suggesting that specialist mathematical knowledge is not an issue for didacticians or teacher educators, or is taken for granted.

These lists of competencies reflect the forms of knowledge that didacticians need in order to work effectively with teachers, and their complex inter-relationships with teachers own knowledge. Jaworski (2008b) offered a model to illustrate the 
complexity and interconnection of mathematics teacher-educators' knowledge with that of teachers (See Figure 1)

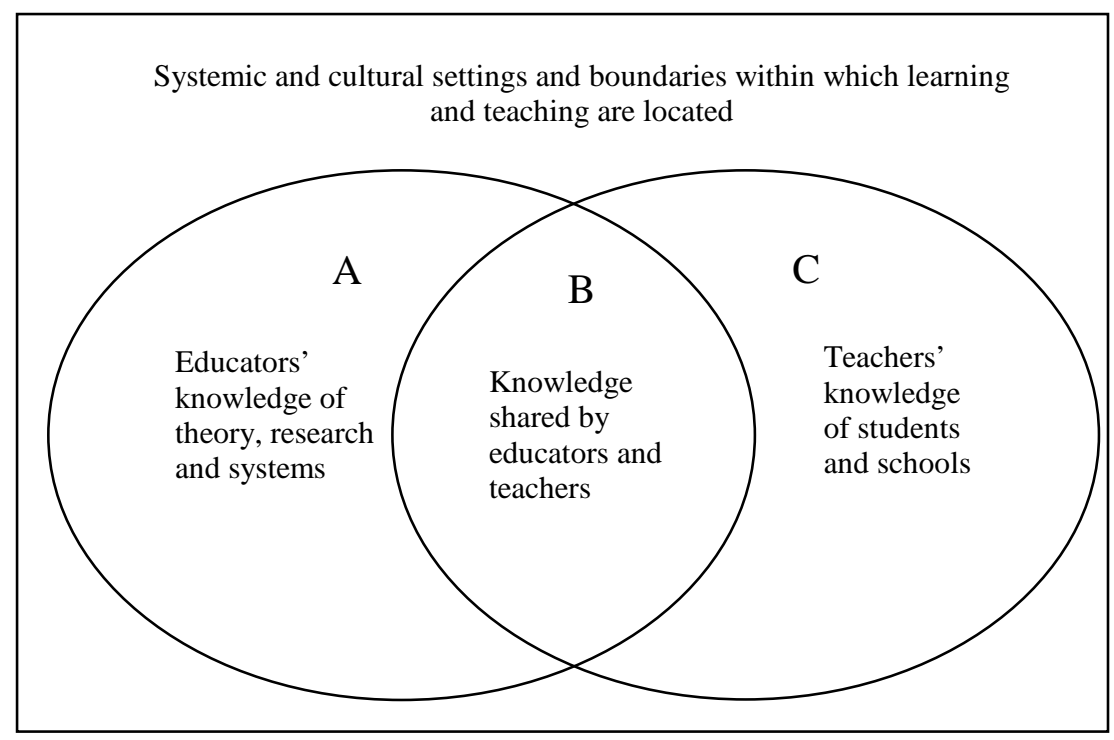

Figure 1: Knowledge in teacher education (Jaworski, 2008b)

The region B (The intersection of A and C) represents the knowledge shared by educators and teachers and has elements of mathematics, didactics and pedagogy.. Thus, although these forms of knowledge may be different according to the practices to which they relate, they present a basis for communication between the two groups. Knowledge in $B$ grows through the specialist knowledge of $A$ and $C$ and the mutual research-inquiry of both teachers and educators in promoting mathematics learning in classrooms. This reciprocity fosters joint respect for the differing qualities that teachers and educators bring and can result in trusting relationships with powerful potential for effective classroom development.

To summarise from the above, the complexity of teacher and teaching knowledge is recognized and theorized in a range of models and frameworks which link knowledge and practice. For didacticians or teacher-educators, knowledge and practice relate to those of teachers, especially in the need for all to be reflective practitioners. However, the roles of the two groups of practitioners are different and this is reflected in forms of practice and their associated knowledge/competency needs. We explore these relationships further in the next section.

\subsection{The continuing professional development of teachers and didacticians}

It has been recognized that developing high quality teachers and effective teaching are crucial for improving students' achievement in mathematics (National Mathematics Advisory Panel 2008; Sowder 2007). Researchers have examined various modes of 
teacher professional developments (PD) and different approaches to developing teachers' expertise in mathematics teaching (e.g., Bednarz, Fiorentini, and Huang 2011; Even and Ball 2009; Li and Even 2011). Simon (2008) classified PD programs into two categories, those with process goals only, and those with content and process goals. The former, which include Japanese lesson study and teacher inquiry or research, do not seek to promote particular new (content) knowledge; rather teaching development is supported through thoughtful reflective engagement. The latter commonly consist of courses or workshops in which teacher educators aim to promote particular mathematical and pedagogical concepts, skills and dispositions.

Some studies (e.g., Archibald, Coggshall, Croft, and Goe 2011; Desimone 2009) have explored the relationship between PD program and student performance in mathematics, suggesting that an effective PD programme should include the following characteristics, which combine elements of Simon's two categories:

- alignment with shared goals (school, district and state) and assessment;

- focusing on core content and modeling of teaching strategies for the content;

- inclusion of opportunities for active learning of new teaching strategies;

- provision of opportunities for collaboration among teachers; and

- inclusion of embedded follow-up and continuous feedback . (Archibald et al. 2011,p. 3)

Ponte (2011) also refers to courses which have both process and content goals: in face to face sessions, teachers are introduced to tasks which exemplify new curriculum orientations; they also collaborate in carrying out and reflecting on classroom activity and researching professional practice. Pepin, Gueudet and Trouche (2013) discuss teachers’ learning through interacting with various resources including textbooks, teaching reference books, manipulative activities (both hands-on and virtual), videos, on-line resources, and technological tools and so on. They conclude that particular resources (together with necessary support, either systemically or individually) have the potential to unite 'participants' (e.g., mathematics teachers; teacher educators; pupils) as a working collective.

The value, for teachers, of using various resources and/or of participating in effective PD projects to develop their professional competences is clear. However, it 
is debatable what constitutes 'effective' PD and problematic to assume there are professional development leaders who are able and readily available to provide high quality resources and effective professional development programs (Even 2005). Even has shown the diversity of qualifications internationally for such provision and the scarcity of training for the providers. It is also clear that providers are often not reflective on, or critical of the nature of their provision, the extent to which it is effective, or its suitability for purpose (Chapman 2008). Based on a longitudinal study on developing teacher leaders/providers of PD, Even (2008) called for examining issues of PD provision in mathematics teaching widely, in relation to the culture and context in which it is situated as well as the relationships between the various participants.

We have mentioned above, for both teachers and didacticians, that developing as reflective practitioners is seen widely as valuable for effective development. Constantly reflecting on-action and in-action (Schön 1987) are seen as a fundamental feature of mathematics teacher educators' learning as well as of teachers' learning (Cochran-Smith 2003, 2009; Jaworski 2008a; Tzur 2001; Zaslavsky, 2008; Zaslavsky and Leikin 2004). For example Cochran-Smith (2003) suggested that being reflective is a fundamental way of looking at one‘s own practice through a critical lens and comparing it to the work and theory of others. Zaslavsky (2008) proposed a model that provides insight into the role of teacher-educators as designers and orchestrators of tasks that foster teacher learning, and at the same time highlights the dynamic nature of teacher-educators' practice and development. In her model (2008) the crucial mediating objects are mathematical tasks and the learning process is one of reflective engagement (see Figure 2). Zaslavsky acknowledged that the demands on teacher-educators are enormous and multi-faceted but the overarching demand is to be a reflective practitioner in all phases of work.

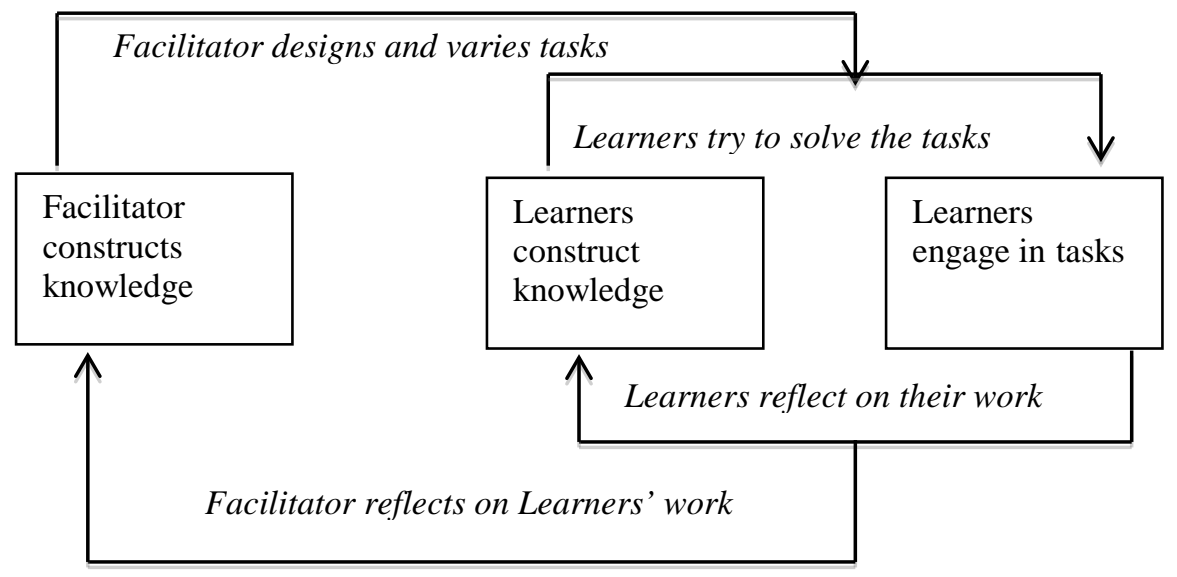


Fig. 2. Task-based knowledge of teachers and teacher educators. (Zaslavsky, 2008)

To examine teacher and teacher educator learning, Jaworski (2001, 2003, 2008a) developed a model of co-learning between teachers and teacher educators in promoting classroom inquiry. Co-learning is a process of working together to explore common interests, through which the various partners all learn from the process. Rather than conceptualising PD as a one-way learning process from the providers to the teachers, co-learning inquiry emphasizes the collaborative potential of joint activity and formation of communities of inquiry. Communities of inquiry emphasize "the importance attached to meta-knowing through reflecting on what is being or has been constructed and on the tools and practices involved in the process." (Wells 1999, p. 124). They can be seen to derive theoretically from a transformation of Wenger's theory of Community of Practice, having, in Wenger's terms important elements of mutual engagement, joint enterprise and shared repertoire.

Within a community of inquiry, teachers and teacher educators have learned from operating with and reflecting on three levels of inquiry-based activities which lead to knowledge and power:

Level one: mathematical power; involving mathematics and provision of classroom mathematical activities for students’ effective learning of mathematics;

Level two: pedagogical power; involving mathematics teaching and ways in which teachers think about developing their approaches to teaching;

Level three: educative power; involving the roles and activities of teacher educators in contributing to developments in levels one and two (Jaworski 2001).

Since the work of Dewey (1933), inquiry has been linked closely with notions of reflection, seeing reflection as action-oriented, "Demand for the solution of a perplexity, is the steadying and guiding factor in the entire process of reflection" (Dewey, 1933p. 14). Further, Kemmis, a leading proponent of teacher action research, writes "We are inclined to think of reflection as something quiet and personal. My argument here is that reflection is action-oriented, social and political. Its product is praxis (informed, committed action) the most eloquent and socially significant form of human action.” (1985, p. 141). These arguments suggest that a questioning attitude, an inquiry-based approach to reflective practice is important to 
development.

However, such a questioning attitude needs to addressed to the use of inquiry approaches per se, their desired and achieved outcomes. The use of an occasional inquiry-based task, or some resource rooted in inquiry may not achieve any significant development and may result in disillusionment for the practitioner. Nevertheless, for some practitioners, inquiry becomes central to their practice - $a$ way of being or a professional stance. According to Cochran-Smith and Lytle (1999), “Taking an inquiry stance means teachers and student teachers [and didacticians] working within inquiry communities to generate local knowledge, envision, and theorize their practice, and interpret and interrogate the theory and research of others” (p.289). Developing inquiry as a way of being involves teachers and educators in taking on the mantle of inquiry so that it permeates all thought and action (Jaworski 2004a). The essence of such inquiry activity is its collaborative nature in which practitioners learn together and support each other in developing, perhaps risky, new forms of practice.

A community of inquiry, therefore, seeks to challenge the status quo, to start to question and to look critically at what alternatives might be possible; then, to start to think and act differently. It is this critical element, overt to a community of inquiry, that distinguishes a Community of Inquiry in general from a Community of Practice. Wenger (1998) has suggested that one element in belonging to a community of practice is that of alignment with the norms and expectations of that practice. However, such alignment can perpetuate ineffective practices - those that do not achieve the goals on which didacticians, teachers and other stakeholders would agree. The nature of a community of inquiry is such that alignment becomes critical through inquiry (Jaworski 2006). Thus teachers and educators taking on an inquiry stance, or an inquiry way of being, engage with critical alignment: they look critically at what they are doing and how they are doing it while engaging in practice. The critical nature of inquiry leads to possibilities for development in practice. Thus we see a consistency between demands for teachers and educators to develop as reflective practitioners and the conceptualisation of critical alignment through inquiry.

Kemmis (1985) and others (e.g. Elliott, 1991; McNiff, 1988) have linked action-based reflection to inquiry in forms of action research in which teachers are encouraged to engage to improve their practice. One of the pioneers of the action-research 
movement, Stenhouse (1984), has written that research is "systematic inquiry made public”, a statement that links inquiry firmly with research. Jaworski (2003) promoted ideas of research as a tool for developmental practice: as well as studying development, research can inform and foster development. Kieran, Krainer and Shaughnessy (2013) discuss didacticians and teachers working together in communities of inquiry to co-produce professional knowledge and scientific knowledge through research. They emphasize three salient features of research where the teacher is viewed as a key stakeholder:

- reflective, inquiry-based activity,

- a significant action-research component, and

- dynamic duality of research and professional development.

They suggest that "given the potential for professional growth from the expanded roles for both classroom teachers and researcher alike, and the growing documentation of long-term benefits for researchers, teachers, and their students from such collaborative research, a case can be made that all countries should consider implementing systematic integration of linked research and practice” (Kieran et al. 2013, p.388). Thus, a community of inquiry where the teacher is included as a key stakeholder has the potential for promoting professional growth of both teachers and didicaticians, and also of producing professional and scientific knowledge as well.

To summarise from the above, PD programmes with 'process goals only' (Simon 2008) become more prevalent where reflective practice, communities of inquiry and collaboration between teachers and diedacticians are key goals. Nevertheless, it is important to recognize that inquiry per se is not a developmental panacea. The researchers referenced above do not suggest that teachers' engagement in inquirybased practice will, of itself, lead to improvements in teaching. The trends towards collaborative inquiry between teachers and didacticians depend on the building of respectful and trusting relationships to which both groups bring important knowledge. We see versions of such relationships in the papers of this special issue with a critical discussion of emergent tensions and a questionable outcome in at least one case (Goodchild, this issue).

\subsection{Theoretical perspectives and their uses relating to changes in practice of teachers and of didacticians}

The literature we have addressed above has emerged historically through a period 
of change in terms of the fundamental theoretical perspectives that have underpinned research projects into mathematics teaching and its development. We characterize these broadly as the eras of constructivist theories and sociocultural theories with considerable overlap between them. To risk being simplistic, we might differentiate these areas of theory according to their focus on the (cognitive) development of the individual (student, teacher or didactician) versus development seen as participation in sociocultural settings. In the former, often based in Piagetian constructivism, development and learning are seen in terms of the construction of knowledge by learners in which learners make sense of their experiential worlds which include social interactions. Knowledge is individual and so communication has to be explained (Cobb, 1988; von Glasersfeld, 1987; Steffe and Thompson, 2000). In the latter, learning and development are seen in terms of Vygotskian theory of the development of knowledge in social settings through mediational processes involving use of tools of which language is central to learning and development. Knowledge is rooted in social processes in which individual knowledge grows integrally with social participation (Bruner 1985; Wertsch 1991; Lerman 1996). Sociocultural theory encompasses a range of theories including situated cognition (Lave 1988; Kirshner and Wilson 1997), community of practice theory (Lave and Wenger 1991; Wenger 1998), activity theory (Leont'ev 1997; Engestrom 1999) and Valsiner's Zone theory (Valsiner, 1997). Some scholars see constructivism and sociocultural theory as forming incommensurable paradigms (Lerman 1996; Steffe and Thompson 2000) whereas others have sought a common or middle ground (Confrey 1995; Sfard 1998).

The reform movement in the United States, represented by the NCTM standards (e.g., NCTM, 1991) built on constructivist theory. The standards encouraged approaches to practice based in constructivism, promoting innovative classroom activities and modes of teaching, often inquiry-based, and had an influence internationally. These forms of practice broke away from prevailing modes of 'direct instruction' (e.g. Romberg and Carpenter 1986) and encouraged problem solving and investigational work for learners of mathematics (Banwell, Saunder, and Tahta 1972; Love 1988; Mason, Burton, and Stacey 1982; Schoenfeld 1986; Silver 1985). This movement coincided with a growing interest in students' mathematics learning as a process of individual mental (re)construction (Hart 1981; Skemp 1971; Steffe 1983; von Glasersfeld 1987). It was an unsurprising progression to start to see teachers’ learning 
about mathematics teaching also in constructivist terms (Confrey 1990; Cooney 1984; Jaworski 1994; Simon and Schifter 1991).

In a book stemming from six years of a PME working group on inservice education of mathematics teachers (Jaworski, Wood and Dawson 1999), various authors wrote about professional development activities stemming from constructivist principles. One message, that came across clearly, involved the dilemmas that teachers faced in bringing innovative practices to their classrooms; changes in classroom practice, without changes in ways of thinking and understanding practice led to issues and tensions (Carter and Richards 1999; Irwin and Britt 1999). Another message concerned the limited value of short, small-scale professional development events, rooted in constructivist theory, for promoting changes in practice. Teachers enjoyed their participation in the events but continued as before when back in the classroom (Murray, Olivier and Human 1999). It became clear that instructing teachers in constructivist-based innovative practices was a problematic way of promoting development in classrooms. Already at this time we started to see more collaborative approaches between teachers and educators directed toward changes in practice and dealing with the associated tensions (Breen 1999; Krainer 1999). Lerman (2006) writes, "For many years we have been aware that teacher education courses, in general, make little difference to how teachers will teach .... . Socio-cultural theories and indeed sociological theories are well placed to shed light on the problem” (p. 363).

During this period (largely the 1990s) collaborative projects became more evident. Still based in constructivism, we saw both large and small-scale projects involving didacticians and teachers working together (e.g., Jaworski, 1998; Krainer, 1999;; Simon \& Schifter 1991;; Wood, Cobb, Yackel and Dillon, 1993) Although the focus was mainly on the learning of teachers, nevertheless it was clear that didacticians were also learning from this work. A conference hosted in Taiwan gave opportunity for an international discussion around these matters (Lin and Cooney 2001 - see particularly chapters by Krainer and Jaworski). Some scholars were moving into much larger scale programmes, recognizing the limited effects of small scale activity. Such programmes often encompassed groups of schools or school districts, government sponsored projects and overt collaboration between researchers and teachers. Theoretical perspectives widened to consider social, systemic and organisational 
factors (Cobb, P., \& Jackson, 2011;Confrey, Castro-Filho, \& Wilhelm, 2000; Krainer \& Zehetmeier, 2013)

Some scholars in mathematics teacher education have drawn more explicitly on sociocultural theory and associated frameworks related to Vygotskian perspectives to guide research into the education of teachers and associated learning of educators/didacticians. Some of the earliest published work can be found from Italy where Bartolini Bussi and colleagues drew on Activity Theory to conceptualise their collaboration with primary school teachers in projects to foster mathematical discussion in classrooms (Bartolini-Bussi 1991). However, some reports are not so explicit about their theoretical groundings. Lerman (2006), reviewing Research Reports from 30 years of PME, questioned how a Research Report could be classified as sociocultural: two aspects of his classification are (1) that "well-known authors in the field of socio-cultural research are cited, such as Vygotsky, Wertsch, Davydov, Daniels, Lave, Wenger, and so on"; and (2) "that the authors base their work on the notion that learning and/or meaning-making originate on the social plane, in social interactions, in language and/or in enculturation.” (p. 351). In contrast, he suggests, "the study of social interactions per se would not lead to the Report being classified as drawing on socio-cultural theory (p. 350).

Llinares and Krainer (2006), suggested that research on teaching development, and the associated development of teacher educators, has centred on reflective practice, and on collaboration and community building. For example, Tzur (2001) provided reflective self-studies of his own developmental trajectories, as mathematics learner, mathematics teacher, mathematics teacher educator and mentor of fellow mathematics teacher educators to identify critical events and experiences that advanced his professional knowledge and practice. This knowledge has evolved through his experiences as a teacher educator over a long time period, largely conceptualised in constructivist terms. Where collaboration and community building are concerned, Linares and Krainer (2006) talk of "Professional development as a social process". This might involve overt use of theory "in order to understand what encourages or inhibits teacher learning and development” (p.444). They point particularly to research by Zaslavsky and Leikin (2004) who have presented a three-layer model to relate the development of teacher educators to that of teachers and students and thus to highlight promoting and hindering factors that influence mathematics teacher 
educators' practice. It is clear in such models that collaboration and community are central to teaching development, but, without explicit reference to Vygotskian frameworks as suggested by Lerman (above), they would not be regarded as taking explicitly a sociocultural theoretical perspective. Also, drawing on Vygotsky does not necessarily imply a sociocultural perspective. For example, Lin (2002) discusses a research collaboration between a researcher and several teachers in Taiwan with a theoretical framework involving reflection, cognitive conflict and social interaction. This framework is seen, explicitly, as being social constructivist: the author draws on Vygotskian theory to explain ways in which social interaction contributes to learning and on Piaget to explain cognitive conflict. Potari and Jaworski (2002) discuss findings from a collaborative project between researchers and teachers using a theoretical construct "the teaching triad" drawn from research conducted in a social constructivist perspective. However, they recognised that a constructivist analysis of dialogue could not account for the whole picture of classroom activity and tensions in decision making. Thus, their further analysis turned to Activity Theory to account for issues and tensions related to differing perspectives revealed in the research (Jaworski and Potari 2009). Activity theory (Leont'ev 1978, 1979; Engeström 1999) has been found especially valuable in in making sense of complex issues and tensions in professional development relationships (e.g., Jaworski and Goodchild 2006; Potari et al. 2010)

Recent research has considered learning and development within communities in which the learning of individual members of a community, students, teachers and teacher educators, has been addressed through more participatory perspectives captured in a growing volume of published works including an ICMI study volume (Even and Ball 2008), a volume of an international handbook (Krainer and Wood 2008) a volume of papers deriving from presentations at ICME XI in Mexico (Bednarz et al. 2011) and a Special Issue of the Journal of Mathematics Teacher Education (JMTE, 2010,13.5 and 13.6). The JMTE special issue on mathematics teacher and mathematics teacher educator change demonstrates the power of a range of theoretical perspectives in investigating teacher and teacher educator change (Goos and Geiger 2010). In a review of the collection, Goos and Geiger suggested that each article has something to say about teachers' identities and how they have changed; they thus chose to analyse the whole from a sociocultural perspective based in 
Valsiner's Zone theory, deriving from Vygotsky’s (1978) Zone of Proximal Development (ZPD). The idea of ZPD has been used extensively to characterise student learning of mathematics with teacher support (e.g. Newman, Griffin and Cole 1989). More recently it has become also a tool for analysis of development of teachers and teaching. Goos (2005) and Blanton Westbrook and Carter (2005), drew on Valsiner's (1997) extension of the ZPD to two other overlapping zones; the Zone of free Movement (ZFM) and the Zone of Promoted Action (ZPA). This combination of three zones (ZPD/ZFM/ZPA) allowed characterisation of teachers' understanding of student-centred inquiry and a perspective of the teacher-as-learner (Goos and Geiger 2010). Goos and Geiger extend their discussion of zone theory to consider the “researcher as learner”, asking "How might researchers who work with teachers develop new knowledge, beliefs, awareness, goals and practices?” and presaging the "future socio-culturally oriented research into the learning and development of mathematics teacher educator-researchers” (p. 506).

Thus, our theoretical sketch above shows, historically, a shift from research based in constructivist theories towards a more social ‘turn’ (Lerman 2000). The latter includes research that is clearly rooted in sociocultural theories deriving from Vygotsky and followers, and research that focuses on collaboration and community, possibly from social-constructivist perspectives, without addressing sociocultural origins. Although we do not have space to develop the theme here, it seems that, in research reports, there is often a transposition from a theoretical perspective (such as constructivist or sociocultural theory) towards practices which are seen as derivative of the theory, but without making this explicit. A reason for requiring a more overt clarification of the theoretical origins underpinning teaching practices (e,g, those cited from Lerman) is to make evident the assumptions on which research findings are based and reveal any tensions or contradictions arising from theoretical inconsistency.

To conclude Section 2, we see the trends highlighted in this section continuing in the papers presented in this special issue, summarized in Section 3 below. These papers both expand our three areas of exploration and extend them to recent developments in theory and practice.

\section{The current issues}


In the subsections that follow, we provide an introduction to the main themes of the eleven articles included in this issue. They include three major areas:

- connections between teachers and didacticians' professional developments in mathematics,

- practice-based didacticians' knowledge and professional development, and

- university-based didacticians’ knowledge and professional development.

\subsection{Connections between teachers and didacticians' professional developments in mathematics}

To address the divide of research and practice, Goos (2014) offers an analytical approach to examining how researchers and teachers can work together to produce both theoretical and practical knowledge through participating in differing mathematics teacher education programmes. Drawing on the concept of communities of practice (Wenger 1998), Goos's framework focuses on how partnerships between researchers and teachers are initiated, how participants negotiate their roles and expectations of each other, and how they benefit from the joint enterprise. Goos provides a detailed analysis of three selected programmes, to reveal that mutuality of researcher and teacher motivations, roles, and purposes, and complementarity of their expertise and knowledge are crucial for successful collaborations. She argues further that it is essential to build two-way connections between communities to support mutual engagement across the boundaries and discusses the implications for the roles of mathematics education researchers who work as teacher educators and professional developers.

Sztajn, Wilson, Edgington, and Myers (2014) examine how researchers and teachers work together as partners within a mathematics professional development (MPD) setting to exchange their knowledge and to improve their own practice. They use the concepts of community of practice, boundary encounters and boundary objects (Wenger, 1998) to conceptualize the process of knowledge exchange between researchers and teachers. They carried out the MPD using a design research approach (Cobb et al. 2003). This involved their use of research-based knowledge (concerned with students' mathematics and mathematics learning) among researchers and teachers to improve the practices of both the research and the teaching communities. They argue that the MPD with research-based goals promotes partnership among 
researchers and teachers in which teachers are interested in the research results. Although both researchers and teachers had different expectations for the MPD, both groups played the dual roles of learners and guides for MPD encounters.

Goos (2014) and Sztajn and her colleagues (2014) both examined the partnership between teachers and researchers from the perspective of communities of practice. Goos identifies the importance of building mutual respectful and beneficial connection between two communities to develop successful collaborations while Sztajn et al. describe the process of using research-based knowledge to improve practices of both teaching and researching communities within a MPD.

\subsection{Practice-based didacticians' knowledge and professional development}

Mathematics specialist coaches are a unique group of practice-based didacticians who work with practicing teachers in schools. Campbell and Malkus (2014) report one aspect of a longitudinal research project conducted in the United States that was designed to prepare elementary school mathematics specialist-coaches, and evaluate the effect of qualified specialist coaches on student achievement. A conceptual framework of co-learning between specialist-coaches and teachers (Jaworski, 2001) guides the designing and implementing of the project, where a specialist-coach is to serve as a "more knowledgeable other" for a community of practice in a school, and ultimately to impact both the knowledge and professional practice of teachers and the school's mathematics programmes as a whole. The authors examine the changes in specialist-coaches' mathematical content knowledge, mathematical knowledge for teaching, and beliefs regarding mathematics teaching and learning over the preparation programme and during the specialist-coaches' first years of service in a school. These specialist-coaches' mathematical content knowledge grew and their beliefs became more aligned with a sense making perspective during the preparation programme, and their changed state persisted throughout 2-3 years of service as specialist-coaches.

Barlow and her colleagues (2014) examined coaches’ views of effective coaching. They used a video-stimulated survey (Video Assessment of Coaching) to collect 28 mathematics coaches' responses to open-ended questions after watching a video featuring the practices of a novice coach leading a coaching cycle (pre-lesson conference and post-lesson conference). The data analysis reveals that all participants 
emphasized the importance of coaching roles in interacting with teachers about mathematics content and student learning, promoting teacher reflection, and negotiating professional relationships as the coaching literature suggests, but they expressed different views of implementing these roles. What the participants expressed regarding implementation of effective coaching is not aligned with what the literature suggests. This disparity emphasises the importance of developing coaches' views on effective practice through their practices of serving as coaches in a school.

Huang, Su and Xue (2014) present a case study on co-learning of teaching researchers (a group of practice-based didaciticians) and practicing teachers in China. They describe two major infrastructures of professional development, namely, a teaching research system and a teaching ranking system. Within these systems, they introduce a unique Chinese lesson study, parallel lesson study (PLS), and further frame this study using co-learning of teaching researchers and practicing teachers within communities of inquiry aimed to pursue exemplary lessons through PLS. They document what teaching researchers and practicing teachers learned through three cycles of repeated teaching experiments (designing, delivering and reflecting) within each of the lesson study groups and across them. The data analysis reveals that not only the practicing teachers developed their instructional competences such as improving instructional process, selecting and sequencing mathematical tasks, and developing professional vision, but also the teaching researchers developed their professional capacity including effectively carrying out teaching research activities, mentoring teachers, and deepening the understanding of teaching.

All these three articles focus on knowledge and professional learning of practicebased didacticians, but they address different aspects. Campbell and Malkus (2014) focus on how coaches' knowledge and beliefs (concerned with teaching and learning in mathematics) change and sustain after completion of a specialist-coach preparation programme, and during coaching in schools while Barlow and her colleagues (2014) center on novice coaches' views about effective mathematic coaching. In contrast, Huang and colleagues examine how practice-based didacticians (teaching researchers) learn through supervising PLS within a traditional and job-embedded teaching research system in China. The nature of Chinese didacticians' learning is closely related to improving class teaching and developing teachers’ practice. Methodologically, Both Campbell and Malkus, and Huang and his colleagues use the 
framework of community of inquiry while Barlow and her colleagues employ a videostimulated survey.

\subsection{University-based didacticians' knowledge and professional development}

Tirosh, Tsamir, Levenson, Barkai, and Tabach (2014) start from the position that using videos as a tool for prompting teachers’ learning has been widely established (Jaworski, 1990; Santagata and Guarino 2011; Sherin 2007). They examine the use of video as a tool for promoting inquiry among preschool teachers and didacticians. Preschool teachers videotaped their teaching, in which they implemented selected tasks, and shared their videos with other teachers and didacticians. The sessions where the teachers and didacticians watched and discussed these videos were recorded and viewed later by didacticians. The multiple uses of video led to inquiry at several levels. Teachers inquired into the practice of implementing tasks with children, evaluating children's knowledge, and the practice of using video as a tool.

Didacticians inquired into their practice of research with children, their practice as teacher educators, the use of video as a tool in professional development, and the use of video in their inquiry process. They discuss the implications for building community of inquiry through using videos in professional development programs.

Coles (2014) addresses two questions of how mathematics teachers learn from using videos and how didacticians can support such learning of mathematics teachers. Based on literature reviews, and his own research with teachers, Coles identifies different modes of using videos and concludes that teachers can learn from videos if they can avoid evaluative discourse about what they see, in particular at the start of discussion. Thus, to establish a discussion norm, didacticians needs to listen in a particular way (engage in "heightened listening") in which they pay attention to what teachers say and what kind of things teachers say. The author argues it is critical to have "heightened listening” in order to facilitate productive discussions surrounding the use of videos.

Anthony, Hunter and Thompson (2014) explore one teacher's learning journey during an intervention project, and one year after completion of the project from an activity theory framework (Engestrom 2001). They draw on the teacher's self-report of his journey one year after his participation in an intervention designed to support the introduction of mathematical inquiry practices. Anthony et al. describe the nature of 
the teacher's learning during and after the intervention project, and identify the factors that supported expansive learning (Engeström and Sannino 2010). Reflecting on the teachers' learning journey, Anthony et al. (2013) express what they learned regarding the provision of research based tools to support learning, the provision of space for individual and collective learning, and the provision of a safe learning environment both within the programme, the class, and the wider professional community. They argue the importance of these factors in understanding transformational changes associated with ambitious pedagogy.

Sakonidis and Potari (2014) examine mathematics teacher educators’ professional learning in two different contexts: collaborating with teachers in developing a community of inquiry into mathematics teaching in a school-based teaching research programme, and initiating teachers in research practice through inquiry in a mathematics education course. By utilizing an Activity Theory perspective (Engestrom 2001), the authors analyze their own activity in interacting with teachers' activity, identifying its nature and transformations that frame their own professional learning. The data analysis reveals that mathematics teacher educators' professional learning is the outcome of a continuous process of becoming aware of their own activity and its transformation in relation to that of the teachers. Meanwhile, they also identify crucial factors that prompt the transition of their activity into a joint activity with teachers.

Building on the nationwide mathematics teaching developmental research projects in Norway that are based on establishing communities of inquiry comprising school teachers at all grades and university-based didacticians, Goodchild (2014) examines the challenges associated with the implementation of the projects. These projects are based on the assumption that teachers taking an inquiry stance in their practice can assert their agency to develop their teaching to enable improved students' learning. However, a case study of a group of upper secondary teachers who are working together with didacticians on algebra topics questions the fundamental assumption. The case exposes tensions between the design of the projects as conceived and motivated by the didacticians and the implementation received and pursued by the teachers. Teaching is observed to exist in alignment to regular practice through the interaction of strong constitutional, institutional, social and professional forces, which inquiry alone appears unable to realign. The author argues that teaching development 
could occur through a gradual extrapolation of practice as teachers implement approaches that they learn from the experience of others and first imagine into their own practice.

Rowland, Turner, and Thwaites (2014) document their professional learning as mathematics teacher educators and researchers during the process of developing and applying the Knowledge Quartet (KQ), a theory of mathematics teacher knowledge, with a focus on classroom situations. Rowland et al. found that KQ research brought about new awarenesses of several important components of promoting mathematics teachers' learning. These aspects include activating novice teachers' propositional knowledge through focused reflection on teaching using the KQ framework, strategic use of representations and examples in classroom teaching, purposeful use of novice teacher generated videos for mathematics methods courses, and reviewing and reflecting teaching using the KQ framework. They illustrate a symbiotic relationship between research into teaching and learning in classrooms and the mathematics teacher educators own professional development.

The six studies focusing on co-learning of university-based didacticians’ and teachers utilize theoretical perspectives (community of practice, activity theory, expansive learning theory, enactivist ideas, and narrative inquiry) which are largely socio-culturally based. Tirosh and her colleagues (2014) (from the perspective of community of practice) and Coles (2014) (from the enactivist notions) examine teachers' and didacticians' learning through use of videos. Tirosh et al. emphasize using videos at multiple levels for examining learning of children, teachers and researchers while Coles focuses on questioning skills in drawing teachers' attention to concrete details before moving toward abstract discussions. Anthony et al. (2014) and Goodchild (2014) examine teachers' learning through professional development programmes. Anthony et al. describe a teacher's success in expansive learning during the intervention programme and one year after completion of the program while Goodchild raises the tension between didacticians'intentions and participating teachers' practices from the perspective of community of practice. Sakonidis and Potari (2014) and Rowland et al. (2014) examine their own learning: Sakonidis and Potari through investigating a mathematics education course and a school-based teaching research program based on activity theory; and Rowland et al through developing and applying their theory of Knowledge Quartet through narrative inquiry. 
In summary, three studies address practice-based didacticians's competence (knowledge, skills and beliefs) and its development. The other eight articles focus university-based didacticians' learning through teaching, researching and conducting professional development programmes. The disparity is interesting in its own right and raises questions for further exploration (such as the opportunities and constraints afforded by these differing situations) These studies emphasise a preference for adopting a socio-cultural perspective to examine teachers and didacticians' learning, and we suggest this might be seen as trend in studies of developmental practice in mathematics teaching and learning.

\section{The contribution of this special issue}

This special issue marks an important transition in perspectives of teacher and teaching development. Rather than seeing professional development as activity organized for teachers by didacticians, through which teachers learn, it conceptualizes development in terms of mutual learning through joint engagement in practice. The practices vary, depending on the nature of the relationships between the two groups, the focuses of development, and theoretical perspectives that inform activity (although the latter are largely socio-cultural in nature). A key factor is the learning of the didacticians alongside their teaching colleagues. Mutual activity and respect for the knowledge each group brings are foundations for learning. Moreover, mutuality is overt: both teachers and didacticians recognize their differences of knowledge and its value in and for their learning. Many PD programmes focus on developing reflection and/or inquiry, possibly through engagement of teachers and didacticians in forms of action research. It seems important to recognize that reflection and inquiry, by themselves, are not developmental panaceas. Collaboration and mutual engagement in communities of inquiry can enable development of new forms of practice and provide support where risky new practices are involved. However, it can also raise issues and tensions which have to be addressed. Through such mutual inquiry and addressing of issues, it is possible to achieve complementary goals of didacticians and teachers for the benefit of students who learn mathematics in their classrooms. We find some of the most recent forms of practice and associated theoretical groundings in the papers of this special issue.

\section{References}


Anthony, G., Hunter, R., \&Thompson, Z. (2014). Learning about expansive learning: lessons from one teacher's journey. ZDM- International Journal on Mathematics Education, 46 (2) (this issue). DOI: $10.1007 / \mathrm{s} 11858-013-0553-\mathrm{z}$

Archibald, S., Coggshall, J. G., Croft, A., \& Goe, L. (2011). High-quality professional development for all teachers: Effectively allocating resources. Washington, DC: National comprehensive center for teacher quality.

Askew, M., Rhodes, V., Brown, M., Wiliam, D., \& Johnson, D. (1997). Effective teachers of numeracy. London: King's College. Department of Education and Professional Studies.

Ball, D. L., Thames, M. H., \& Phelps, G. (2008). Content knowledge for teaching: What makes it special? Journal of Teacher Education, 59, 389-407.

Banwell, C. S., Saunders, K. D., \& Tahta, D. S. (1972), Starting points. Oxford: Oxford University Press.

Barlow, A. T., Burroughs, E. A., Harmon, S. E., Sutton, J. T., \& Yopp, D. A. (2014). Assessing Views of Coaching via a Video-based Tool. ZDM- International Journal on Mathematics Education, 46 (2) (this issue). DOI:10.1007/s11858-013-0557-7.

Bartolini-Bussi, M. (1991). Social interaction and mathematical knowledge. In F. Furinghetti (ed), Proceedings of the fifteenth PME conference (Vol. 1, 1-16). Genova, Italy: Department of Mathematics, University of Genova.

Bednarz, N., Fiorentini, D., \& Huang, R. (2011). International approaches to professional development for mathematics teachers. Canada: Ottawa University Press.

Beswick, K., \& Chapman, O. (2012). Mathematics teacher educators' knowledge for teaching. Paper presented at The $12^{\text {th }}$ International Congress on Mathematics Education, Julyl 8-15, 2012, Coex, Seoul, Korea.

Beswick, K., \& Chapman, O. (2013). Mathematics teacher educators’ knowledge. In A. M. Lindmeier \& A. Heinze (Eds.), Proceedings of the 37th Conference of the International Group for the Psychology of Mathematics Education (Vol. 1, p. 215). Kiel, Germany: PME.

Blanton, M. L., Westbrook, S., \& Carter, G. (2005). Using Valsiner’s Zone Theory to interpret teaching practices in mathematics and science classrooms. Journal of Mathematics Teacher Education, $8,1,5-33$.

Breen, C. (1999). Circling the square: Issues and dilemma concerning teacher transformation. In B. Jaworski, T. Wood \& A. J., Dawson (Eds.), Mathematics teacher education: Critical international perspectives ( pp.112-121). London/Philadelphia: Falmer Press

Brown, L., \& Coles, A. (2012). Mathematics teachers and mathematics teacher educator changes: insights through theoretical perspectives. Journal of Mathematics Teacher Education, 13, 375382.

Bruner, J. (1985). Vygotsky: a historical and conceptual perspective. In, J. Wertsch, (Ed.), Culture, communication and cognition (pp.21-34). Cambridge: Cambridge University Press.

Campbell, P.F., \& Malkus, N. N. (2014). The mathematical knowledge and beliefs of elementary mathematics specialist-coaches. ZDM- International Journal on Mathematics Education, 46 (2) (this issue). DOI: 10.1007/s11858-013-0559-6.

Carter, R., \& Richards, J. (1999). Dilemmas of constructivist mathematics teaching: Instances from classroom practice. In B. Jaworski, T. Wood \& A. J., Dawson (Eds.), Mathematics teacher education: Critical international perspectives (pp.68-76). London/Philadelphia: Falmer Press

Chapman, O. (2008). Mathematics teacher educators' learning from research on their instructional practices. In B. Jaworski \& T. Wood (Eds.), The international handbook of mathematics teacher education: The mathematics teacher educator as a developing professional (Vol.4, pp. 115-136). Rotterdam: Sense Publishers. 
Cobb, P. (1988). The tension between theories of learning and instruction in mathematics. Educational Psychologist, 22 (2), 87-103.

Cobb, P., \& Jackson, K. (2011). Towards an empirically grounded theory of action for improving the quality of mathematics teaching at scale. Mathematics Teacher Education and Development, 13, 6-33.

Cobb, P., Confrey, J., diSessa, A., Lehrer, R., \& Schauble, L. (2003). Design experiments in educational research. Educational Researcher, 32, 9-13.

Cochran Smith, M., \& Lytle, S. L. (1999). 'Relationships of knowledge and practice: Teacher learning in communities’. In A Iran-Nejad \& C. D. Pearson (Eds.), Review of research in education, 24 (pp.249-306). Washington, DC: The American Educational Research Association.

Cochran-Smith, M. C. (2003). Learning and unlearning: the education of teacher educators. Teaching and Teacher Education, 19, 5-28

Cochran-Smith, M., \& Lytle, S. L. (2009). Inquiry as stance: Practitioner research for next generation. New York: Teacher College Press.

Coles, A. (2014). Mathematics teachers learning with video: the role, for the didactician, of a heightened listening. ZDM- International Journal on Mathematics Education, 46 (2) (this issue). DOI: $10.1007 / \mathrm{s} 11858-013-0541-3$.

Confrey, J. (1990). What constructivism implies for teaching. Constructivist views on the learning and teaching of mathematics (Journal for Research in Mathematics Education, Monograph 4) (pp.107-122+195-210). Reston, VA: National Council of Teachers of Mathematics.

Confrey, J. (1995). How compatible are Radical Constructivism, Sociocultural Approaches and Social Constructivism? In L. P. Steffe \& J. Gale (Eds.), Constructivism in Education.(pp.185-226). Hove, UK: Lawrence Erlbaum Associates.

Confrey, J., Castro-Filho, J. \& Wilhelm, J. (2000). Implementation research as a means to link systemic reform and applied psychology in mathematics education. Educational Psychologist, 35 (3), 179-191

Cooney, T. J. (1984). The contribution of theory to mathematics teacher education. In H. G. Steiner at al.(Eds.), Theory of mathematics education (TME) (pp.120-131). Bielefeld, Germany: University of Bielefeld/IDM.

Desimone, L. M. (2009). Improving impact studies of teachers’ professional development: Toward better conceptualizations and measures. Educational Researcher, 38(3), 181-199.

Dewey, J. (1933). How we think. Boston: D. C. Heath.

Elliott, J. (1991). Action research for educational change. Milton Keynes: Open University Press.

Engeström, Y. (1999). Activity theory and individual and social transformation. In Y. Engeström, R. Miettinen \& R-L Punamäki (Eds.), Perspectives on activity theory (pp. 19-38). Cambridge: Cambridge University Press.

Engeström, Y. (2001). Expansive learning at work: Toward an activity theoretical reconceptualization, Journal of Education and Work, 14(1), 133-156.

Engeström, Y., \& Sannino, A. (2010). Studies of expansive learning: Foundations, findings and future challenges. Educational Research Review, 5(1), 1-24.

Even, R. (2005). Integrating knowledge and practice at MANOR in the development of providers of professional development for teachers. Journal of Mathematics Teacher Education, 8, 343-357.

Even, R. (2008). Facing the challenge of educating educators to work with Practicing mathematics teachers. In B. Jaworski \& T. Wood(Eds.), The international handbook of mathematics teacher education: The mathematics teacher educator as a developing professional (Vol. 4, pp. 57-74). Rotterdam, The Netherlands: Sense.

Even, R., \& Ball, D. L. (Eds.). (2009). The professional education and development of teachers of mathematics—-the 15th ICMI Study. New York: Springer. 
Goodchild, S. (2014). Mathematics teaching development: Learning from developmental research in Norway. ZDM- International Journal on Mathematics Education, 46 (2) (this issue). DOI:

Goodchild, S., \& Sriraman, B. (2012). Revisiting the didactic triangle: from the particular to the general. ZDM-International Journal on Mathematics Education, 44, 581-585

Goos, M. (2005). A sociocultural analysis of the development of pre-service and beginning teachers' pedagogical identities as users of technology. Journal of Mathematics Teacher Education, 8, 1, 35-59.

Goos, M. (2014). Researcher-teacher relationships and models for teaching fevelopment in mathematics education. ZDM- International Journal on Mathematics Education, 46 (2) (this issue). DOI: 10.1007/s11858-013-0556-9.

Hart. K. (Ed.). Children's understanding of mathematics: 11 16. London: John Murray.

Hill, H. C., Ball, D. L., \& Schilling, S. G. (2008). Unpacking pedagogical content knowledge: conceptualising and measuring teachers' topic-specific knowledge of students. Journal for Research in Mathematics Education, 39(4), 372-400.

Huang, R., Xu, S., Su, H., \& Tang, B. (2012, July). Teaching researchers in China: Hybrid functions of researching, supervising and consulting. Paper to be presented at $12^{\text {th }}$ International Conference on Mathematics Education, July 8-15, 2012 Seoul, Korea.

Huang, R., \& Li, Y. (2009). Pursuing excellence in mathematics classroom instruction through exemplary lesson development in China: A case study. ZDM - The International Journal on Mathematics Education, 41, 297-309.

Huang, R., Su, H., \&Xu, S. (2014). Developing teachers' and teaching researchers' professional competence in mathematics through Chinese Lesson Study. ZDM-International Journal on Mathematics Education, 46 (2) (this issue). DOI: 10.1007/s11858-013-0557-8.

Irwin, J. C., \& Britt, M. S. (1999). Teachers’ knowledge of mathematics and reflective professional development . In B. Jaworski, T. Wood, \& A. J., Dawson (Eds.), Mathematics teacher education: Critical international perspectives (pp. 90-100). London/Philadelphia: Falmer Press

Jaworski, B. \& Potari, D. (2009). Bridging the macro-micro divide: using an activity theory model to capture complexity in mathematics teaching and its development. Educational Studies in Mathematic, 72, 219-236.

Jaworski, B. (1990). Video as a tool for teachers' professional development. Professional development in education, 16(1), 60-65.

Jaworski, B. (1994). Investigating mathematics teaching: A constructivist enquiry. London: Falmer Press.

Jaworski, B. (1998). Mathematics teacher research: Process, practice and the development of teaching. Journal of Mathematics Teacher Education, 1, 3-31.

Jaworski, B. (2001). Developing mathematics teaching: teachers, teacher educators, and researchers as co-learners. In F. L. Lin \& T. J. Cooney (Eds.), Making sense of mathematics teacher education (pp. 295-320). Dordrecht: Kluwer.

Jaworski, B. (2003). Research practice into/influencing mathematics teaching and learning development: Towards a theoretical framework based on co-learning partnerships. Educational Studies in Mathematics, 54(2-3), 249-282.

Jaworski, B. (2004). Grappling with complexity: Co-Learning in inquiry communities in mathematics teaching development. In M. J. Høines \& A. B. Fuglestad (Eds.), Proceedings of the $28^{\text {th }}$ Conference of the International Group for the Psychology of Mathematics Education (pp. 17-32). Bergen, Norway: Bergen University College.

Jaworski, B. (2006). Theory and practice in mathematics teaching development: critical inquiry as a mode of learning in teaching. Journal of Mathematics Teacher Education, 9, 187-211.

Jaworski, B. (2008a). Building and sustaining inquiry communities in mathematics teaching development: Teachers and didacticians in collaboration. In K. Krainer \& T. Wood (Eds.), 
International handbook of mathematics teacher education: The mathematics teacher educator as a developing professional (Vol. 3, pp. 335-361). Rotterdam: Sense Publishers.

Jaworski, B. (2008b). Development of the mathematics teacher educator and its relation to teaching development. In Jaworski, B., \& Wood, T. (Eds.). International handbook of mathematics teacher education: The mathematics teacher educator as a developing professional (Vol. 4. pp. 335-361). Rotterdam, The Netherlands: Sense

Jaworski, B., \& Goodchild, S. (2006). ‘Inquiry community in an activity theory frame’. In J. Novotna, H. Moraova, M. Kratka, \& N. Stelikova (Eds.), Proceedings of the 30th Conference of the International Group for the Psychology of Mathematics Education (Vol. 3, pp. 353-360). Prague, Czech Republic: Charles University.

Jaworski, B., Wood, T., \& Dawson, A. J. (1999). Mathematics teacher education: Critical international perspectives. London/Philadelphia: Falmer Press.

Kemmis, S. (1985). Action research and the politics of reflection. In D. Boud, R. Keogh, \& D. Walker (Eds.), Reflection: Turning experience into learning. London: Kogan Page.

Kieran, C., Krainer, K., \& Shaughnessy, J. M. (2013). Linking research to practice: Teachers as key stakeholders in mathematics education research. In M.A. Clements, A. J. Bishop, C. Keitel, J. Kilpatrick, \& F. K.S. Leung (Eds), Third international handbook of mathematics education (pp.361-392). New York: Springer.

Kirshner, D., \& Whitson, J. A. (1997). Situated cognition: social, semiotic and psychological perspectives. London: Lawrence Erlbaum Associates.

Krainer, K. \& Zehetmeier, S. (2013). Inquiry-based learning for students, teachers, researchers, and representatives of educational administration and policy: reflections on a nation-wide initiative fostering educational innovations. ZDM - The International Journal on Mathematics Education, 45(6), 875-886.

Krainer, K. (1999). PFL-Mathematics: Improving professional practice in mathematics teaching. In B. Jaworski, T. Wood \& A. J., Dawson (Eds.), Mathematics teacher education: Critical international perspectives (pp. 101-111) . London/Philadelphia: Falmer Press

Krauss, K., Brunner, M., Kunter,M., Baumert, J. , Blum, W., Neubrand, M. et al.(2008). Pedagogical content knowledge and content knowledge mathematics teachers. Journal of Educational Psychology, 100, 716-725.

Lave, J. (1988). Cognition in practice: Mind, mathematics and culture in everyday life. Cambridge: Cambridge University Press

Lave, J., \& Wenger, E. (1991). Situated learning: Legitimate peripheral participation. Cambridge: Cambridge University Press

Leont'ev, A. N. (1978). Activity, consciousness, and personality. Englewood Cliffs: Prentice-Hall.

Leont'ev, A. N. (1979). The problem of activity in psychology, In J. V. Wertsch (Ed.), The concept of activity in Soviet psychology (pp. 37-71). New York: M. E. Sharpe.

Lerman, S. (1996). Inersubjectivity in mathematics learning: A challenge to the radical constructivist paradigm? Journal for Research in Mathematics Education, 27 (2), 133-150.

Lerman, S. (2000). The social turn in mathematics education research. In J. Boaler (Ed.), Multiple perspectives on mathematics teaching and learning. London: Ablex.

Lerman, S. (2006). Socio-cultural research in PME. In A. Gutie' rrez \& P. Boero (Eds.), Handbook of research on the psychology of mathematics education (pp.347-366). Rotterdam, The Netherlands: Sense Publishers.

Li, Y., \& Even, R. (2011). Approaches and practices in developing teachers' expertise in mathematics instruction: an introduction. ZDM- The International Journal on Mathematics Education, 43 (67), 759-762.

Lin P. J. (2002). On enhancing teachers' knowledge by constructing cases in classroom. Journal of Mathematics Teacher Education, 54 (4), 317-349. 
Lin, F. L., \& Cooney, T. J. (2001). Making sense of mathematics teacher education. Dordrecht: Kluwer.

Llinares, S., \& Krainer, K. (2006). Mathematics (student) teachers and teacher educators as learners. In A. Gutie' rrez \& P. Boero (Eds.), Handbook of research on the psychology of mathematics education (pp.429-459). Rotterdam, The Netherlands: Sense Publishers.

Love, E. (1988). Evaluating mathematical Activity. In D. Pimm (Ed.). Mathematics, teachers and children (pp.249-262). London: Hodder and Stoughton.

Mason, J., Burton, L., \& Stacey, K. (1982). Thinking mathematically. London: Addison Wesley.

McNiff, J. ( 1988). Action research: principles and practice. London: Macmillan Education.

Murray, H., Olivier, A., \& Human, P. (1999). Teachers’ mathematical experiences as links to childrens' needs. In B. Jaworski, T. Wood \& A. J., Dawson (Eds.), Mathematics teacher education: Critical international perspectives (pp. 32-40). London/Philadelphia: Falmer Press

National Council of Teachers of Mathematics (1989). Curriculum and evaluation standards for teaching mathematics. Reston, VA: Author

National Mathematics Advisory Panel. (2008). Foundations for success: The final report of the National Mathematics Advisory Panel. U.S. Department of Education: Washington, D.C.

Newman, D., Griffin, P., \& Cole, M. (1989). The construction zone: Working for cognitive change in schools. Cambridge: Cambridge University Press.

Pepin, B., Gududet, G., \& Trouche, L. (2013). Re-sourcing teachers’ work and interactions: a collective perspective on resources, their use and transformation. ZDM-International Journal on Mathematics Education, 45, 929-943.

Perks, P., \& Prestage, S. (2008). Tools for learning about teaching and learning. In Jaworski, B., \& Wood, T. (Eds.). International handbook of mathematics teacher education: The mathematics teacher educator as a developing professional (Vol. 4. pp. 265-280). Rotterdam, The Netherlands: Sense

Ponte, J. P. (2011). Preparing teachers to meet the challenges of statistics education. In C. Batanero, G. Burrill, \& C. Reading (eds.), Teaching statistics in school mathematics-challenges for teaching and teacher education: A joint ICMI/IASE study, DOI 10.1007/978-94-007-1131-0_29, (C) Springer Science+Business Media B.V. 2011

Ponte, J. P., \& Chapman, O. (2006). Mathematics teachers’ knowledge and practices. In A. Gutierrez \& P. Boero (Eds.), Handbook of research on the psychology of mathematics education: Past present and future (pp. 461-494). Rotterdam: Sense Publishers.

Potari, D., \& Jaworski, B. (2002). Tackling complexity in mathematics teaching development: using the teaching triad as a tool for reflection and analysis. Journal of Mathematics Teacher Education, 5, 351-380.

Potari, D., Sakonidis, C., Chatzigoula, A., \& Manaridis, A. (2010). Teachers’ and researchers’ collaboration in analyzing mathematics teaching: A context for professional reflection and development. Journal of Mathematics Teacher Education, 13, 473-485.

Romberg, T. A., \& Carpenter, T. P. (1986). Research on teaching and learning mathematics: Two disciplines of scientific inquiry. In M. C. Wittrock (Ed.), Handbook of research on teaching (pp. 850-873). New York: Macmillan.

Rowland, T., Huckstep, P., \& Thwaites, A. (2005). Elementary teachers' mathematics subject knowledge: The knowledge quartet and the case of Naomi. Journal of Mathematics Teacher Education, 8(3), 255-281.

Rowland, T., Turner, F., \& Thwaites, A. (2014).Research into teacher knowledge: a stimulus for development in mathematics teacher education practice. ZDM- International Journal on Mathematics Education, 46 (2) (this issue). DOI: 10.1007/s11858-013-0564-9.

Sakonidis, H., \& Potari,D.(2014). Mathematics teachers educators'/researchers' collaboration with teahcers as a context for professional learning. ZDM- International Journal on Mathematics Education, 46 (2) (this issue). DOI 
Santagata, R., \& Guarino, J. (2011). Using video to teach future teachers to learn from teaching. ZDMThe International Journal on Mathematics Education, 43(1), 133-145.

Schoenfeld, A. (1985). Mathematical problem solving. New York: Academic Press.

Schön, D.A. (1987). Educating the reflective practitioner. Oxford: Jossey-Bass.

Sfard, A. (1998). On two metaphors for learning and the dangers of choosing just one. Educational Researcher, 27(2), pp. 4-13

Sherin, M. (2007). New perspectives on the role of video in teacher education. In J. Brophy (Ed.), Using video in teacher education (pp. 1-28). Bingley, UK: Emerald Group Publishing Limited.

Shulman, L. S. (1986). Those who understand: Knowledge growth in teaching. Educational Researcher, 15(2), 4-14.

Silver, E. A. (Ed.). (1985). Teaching and learning mathematical problem solving: Multiple research perspectives. Hillsdale, NJ: Lawrence Erlbaum Associates

Silverman, J., \& Thompson, P. W. (2008). Toward a framework for the development of mathematical knowledge for teaching. Journal of Mathematics Teachers Education, 11, 499-511.

Simon, M. (2008). The challenge of mathematics teacher education in an era of mathematics education reform. In K. Krainer \& T. Wood (Eds.), International handbook of mathematics teacher education :The mathematics teacher educator as a developing professional (Vol. 3, pp. 17-30). Rotterdam: Sense Publishers.

Simon, M.A., \& Schifter, D. E. (1991). Towards a constructivist perspective: An intervention study of mathematics teacher development. Educational Studies in Mathematics, 22, 309-331.

Skemp, R. R. (1971). The psychology of learning mathematics. London: Penguin.

Smith, K. (2005). Teacher educators' expertise: what do novice teachers and teacher educators say. Teaching and Teacher Education, 21, 177-192.

Sowder, J. T. (2007). The mathematical education and development of teachers. In F. K. Lester Jr (Ed.), Second handbook of research on mathematics teaching and learning (pp. 157-223). Charlotte, NC: Information Age Publishing.

Steffe, L. P., \& Thompson, P. W. (2000). Interaction or intersubjectivity? A replay to lerman. Journal for Research in Mathematics Education, 31 (2), 191-209.

Steffe, L. P., (1983). The teaching experiement methodology in a constructivist research program. In M. Zweng, T. Green, J. Kilpatrick, H. Pollak, \& M. Suydam (Eds.), Proceedings of the fourth international congress of mathematics education (pp. 469-471). Boston: Birkhauser.

Stenhouse, L. (1984). Evaluating curriculum evaluation. In C. Adelman (Ed.), The politics and ethics of evaluation(pp.75-84). London: Croom Helm.

Sullivan, P., \& Wood, T. (2008). The International handbook of mathematics teacher education. Volume 1. Knowledge and beliefs in mathematics teaching and teaching development. Rotterdam: Sense Publishers.

Sztajn, P., Wilson, P. H., Edgington, C.,\&Myers, M. (2014). Mathematics Professional Development as Design for Boundary Encounters. ZDM- International Journal on Mathematics Education, 46 (2) (this issue). DOI:10.1007/s11858-013-0560-0.

Tatto, M. T., Schwille, J., Senk, S., Ingvarson, L., Peck, R., \& Rowley, G. (2008). Teacher education and development study in mathematics (TEDS-M): Policy, practice, and readiness to teach primary and secondary mathematics. Conceptual framework. East Lansing, MI: Teacher Education and Development International Study Center, College of Education, Michigan State University.

Tirosh, D., Tsamir, P., Levenson, E., Barkai, R., \& Tabach, M. (2014). Levenson. Using video as a tool for promoting inquiry among preschool teachers and didacticians of mathematics. ZDMInternational Journal on Mathematics Education, 46 (2) (this issue). DOI:0.1007/s11858-0130563-x. 
Tsui, A. B. M., \& Wong, J. L. N. (2009). In search of a third space: teacher development in Mainland China. In C. K.K. Chan \& N. Rao (Eds.), Revisiting the Chinese learner: Changing contexts, changing education (pp. 281-314). New York: Springer.

Tzur, R. (2001). Becoming a mathematics teacher-educator: conceptualizing the terrain through selfreflective analysis. Journal of Mathematics Teacher Education, 4, 259-283.

Valsiner, J. (1997). Culture and the development of children's action: A theory of human development (2nd ed.). New York: Wiley.

von Glasersfeld, E. (1987). Learning as a constructive activity. In C. Janvier (Ed.), Problems of representation in the teaching of mathematics (pp. 3-18). Hillsdale, NJ. Lawrence Erlbaum.

Vygotsky, L. (1978). Mind in society. Cambridge, MA: Harvard University Press.

Wells, G. (1999). Dialogic inquiry: Towards a sociocultural practice and theory of education. Cambridge: Cambridge University Press.

Wenger, E. (1998). Communities of practice: Learning, meaning and identity. Cambridge, MA: Cambridge University Press.

Wertsch, J. V. (1991). Voices of the mind. Cambridge, MA: Harvard University Press.

Wood, T., Cobb,P., Yackel, E., \& Dillon, D. (1993). Rethinking elementary school mathematics: insights and issues. (Journal for Research in Mathematics Education, Monograph, 6). Reston, VA: National Council of Teacher of Mathematics.

Yang, Y. (2009). How a Chinese teacher improved classroom teaching in Teaching Research Group: A case study on Pythagoras theorem teaching in Shanghai. ZDM - International Journal on Mathematics Education, 41, 279-296.

Zaslavsky (2008). Meeting the challenges of mathematics teacher education through design and use of tasks that facilitate teacher learning. In Jaworski, B., \& Wood, T. (Eds.). International handbook of mathematics teacher education: The mathematics teacher educator as a developing professional (Vol. 4. pp. 93-114). Rotterdam, The Netherlands: Sense

Zaslavsky, O., \& Leikin, R. (2004). Professional development of mathematics teacher educators: Growth through practice. Journal of Mathematics Teacher Education, 7(1), 5-32. 